\title{
Integration of the South Mato Grosso Indigenous Peoples in the Policy of Fire Control and Prevention and Territorial Mismanagement
}

\author{
SILVA, Anderson Nunes dal. OLIVEIRA, Vanessa Avalo ${ }^{2}$. MAIA, Jaqueline Pinheiro Siqueira ${ }^{3}$.
}

Universidade Estadual de Mato Grosso do Sul (UEMS), Dourados, Brasil.

E-mail para contato: andjur@ outlook.com¹; vanessa.avalo@ outlook.com²; jaquelinepsmaiaadv@gmail.com ${ }^{3}$

\begin{abstract}
The research aims to collect data on fire indices in the Indigenous Lands of the state of Mato Grosso do Sul, in order to conclude that the culture of fire still persists in the indigenous environment, making it possible to foster policies of integration of fire management by these peoples in order to reduce the impacts of fires on the biomes. In the state of Mato Grosso do Sul, in the municipalities of Dourados and Caarapó, there is a predominant formation of Cerrado ecosystems and traces of Atlantic Forest. The dry winter climate combined with poor territorial management makes the cerrado biome propitious to fires. This research was carried out based on the analysis of the INPE Burning Database, in the Dourados and Caarapó Indigenous Lands in the state of Mato Grosso do Sul, on the dates from March 29, 2018 to March 30, 2019. In the period of one year, an intense cluster of fire outbreaks was observed in the areas of Indigenous Lands, located in both municipalities. The research resulted in the finding that in these indigenous areas there was a higher concentration of fire outbreaks, noting that the use of fire by these peoples offers more advantages to the environment than risk and degradation. Fire has been used by indigenous peoples for a long time for a variety of ecological, social and spiritual purposes. But the indiscriminate use of fires has been attributed to the Indians, who, by the way, are longest on Brazilian soil. In fact, the "white man" takes advantage of the indigenous peoples' technique of fire to blame them for the fires, in order to cover up the fact that the biggest problem is the territorial mismanagement of the ecosystems. The municipalities of Dourados and Caarapó are examples that the urban advance on the environment has indiscriminately driven the fires. From this point on, the public authorities must promote firefighting programs integrating the indigenous peoples who have traditional knowledge of fire management, in order to increase safety and minimize the socio-environmental damage caused by the growing urban advance on the environment.
\end{abstract}

Keywords: indigenous lands, urban advancement over ecosystems, fire fighting program, fire management techniques, territorial management. 